\title{
Pseudidiomarina donghaiensis sp. nov. and Pseudidiomarina maritima sp. nov., isolated from the East China Sea
}

Correspondence

Min Wu

wumin@zju.edu.cn

\author{
Yue-Hong Wu, ${ }^{1}$ Yu-Qiang Shen, ${ }^{1}$ Xue-Wei $\mathrm{Xu},{ }^{2,3}$ Chun-Sheng Wang, ${ }^{2,3}$ \\ Aharon Oren ${ }^{4}$ and Min $\mathrm{Wu}^{1}$
}

\author{
${ }^{1}$ College of Life Sciences, Zhejiang University, Hangzhou 310058, PR China \\ ${ }^{2}$ Laboratory of Marine Ecosystem and Biogeochemistry, State Oceanic Administration, Hangzhou \\ 310012, PR China \\ ${ }^{3}$ Second Institute of Oceanography, State Oceanic Administration, Hangzhou 310012, PR China \\ ${ }^{4}$ Institute of Life Sciences and the Moshe Shilo Minerva Center for Marine Biogeochemistry, The \\ Hebrew University of Jerusalem, Jerusalem 91904, Israel
}

Two Gram-negative, aerobic, motile, rod-shaped bacteria, designated strains $908033^{\top}$ and $908087^{\top}$, were isolated from a seawater sample collected from the East China Sea.

Chemotaxonomic characteristics of the two isolates included the presence of iso- $\mathrm{C}_{15: 0 \text {, iso- }}$ $\mathrm{C}_{17: 0}$ and iso- $\mathrm{C}_{17: 1} \omega 9 \mathrm{c}$ as the major cellular fatty acids and $\mathrm{Q}-8$ as the predominant ubiquinone. The genomic DNA G $+C$ contents of strains $908033^{\top}$ and $908087^{\top}$ were 45.5 and $45.2 \mathrm{~mol} \%$, respectively. Phylogenetic analyses based on 16S rRNA gene sequences revealed that the new isolates were related to members of the genus Pseudidiomarina, showing levels of similarity of 95.8-96.6\% with the type strains of recognized species of the genus. The results of DNA-DNA hybridization experiments among these two isolates and Pseudidiomarina sediminum CICC $10319^{\top}$, in combination with chemotaxonomic and phenotypic data, demonstrated that the new isolates represent two novel species of the genus Pseudidiomarina, for which the names Pseudidiomarina donghaiensis sp. nov. (type strain $908033^{\top}=\mathrm{CGMCC} 1.7284^{\top}=\mathrm{JCM} 15533^{\top}$ )

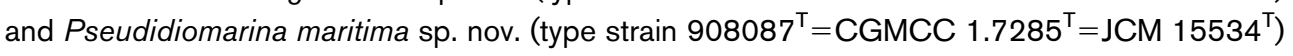
are proposed.
The family Idiomarinaceae, belonging to the class Gammaproteobacteria, was proposed by Ivanova et al. (2004) based on a comprehensive phylogenetic analysis, and the family comprises two recognized genera: Idiomarina (Ivanova et al., 2000) and Pseudidiomarina (Jean et al., 2006). At the time of writing, the genus Pseudidiomarina comprised two recognized species, namely Pseudidiomarina taiwanensis (Jean et al., 2006) and Pseudidiomarina sediminum ( $\mathrm{Hu} \& \mathrm{Li}, 2007)$. Members of the genus contain iso-branched fatty acids with 15 and 17 carbons as the predominant components. In this study, we present a polyphasic study describing two motile

The GenBank/EMBL/DDBJ accession numbers for the 16S rRNA gene sequences of strains $908033^{\top}$ and $908087^{\top}$ are EU600204 and EU600203, respectively.

Transmission electron micrographs of cells of strains $908033^{\top}$ and $908087^{\top}$, maximum-parsimony and maximum-likelihood phylogenetic trees based on 16S rRNA gene sequences, and a table giving the cellular fatty acid contents of strains $908033^{\top}$ and $908087^{\top}$ and related Pseudidiomarina species are available as supplementary material with the online version of this paper. bacteria isolated from a seawater sample. The resultant phylogenetic and phenotypic data showed that the new isolates represent two novel species of the genus Pseudidiomarina.

A seawater sample was collected from the East China Sea

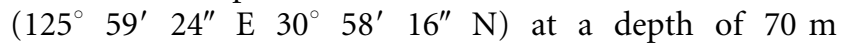
(temperature $16.7{ }^{\circ} \mathrm{C}$; salinity $33.95 \%$ ). Approximately $150 \mu \mathrm{l}$ seawater was plated on marine agar 2216 (MA; Difco). After 3 days aerobic incubation at $25{ }^{\circ} \mathrm{C}$, two nonpigmented colonies, designated strains $908033^{\mathrm{T}}$ and $908087^{\mathrm{T}}$, were picked. The isolates were purified by repeated restreaking; purity was confirmed based on uniformity of cell morphology. Unless stated otherwise, strains $908033^{\mathrm{T}}$ and $908087^{\mathrm{T}}$ were maintained on halophilic medium (HM) containing $3 \% \mathrm{NaCl}(\mathrm{w} / \mathrm{v})$ at $37{ }^{\circ} \mathrm{C}$. $\mathrm{HM}$ contained (per litre distilled water): $\mathrm{NaCl}$ as indicated, $2.0 \mathrm{~g} \mathrm{KCl}, 1.0 \mathrm{~g} \mathrm{MgSO}_{4} .7 \mathrm{H}_{2} \mathrm{O}, 0.36 \mathrm{~g} \mathrm{CaCl}_{2} .2 \mathrm{H}_{2} \mathrm{O}, 0.23 \mathrm{~g}$ $\mathrm{NaBr}, 0.06 \mathrm{~g} \mathrm{NaHCO}_{3}$, trace $\mathrm{FeCl}_{3}, 10.0 \mathrm{~g}$ yeast extract (Difco), 5.0 g peptone (Difco) and 1.0 g glucose ( $\mathrm{pH} 7.5)$ (Ventosa et al., 1982). 
Optimal conditions for growth were determined in MYP medium with various $\mathrm{NaCl}$ concentrations $(0,0.5,1,3,5$, 7.5, 10, 15, 20 and 25, w/v). MYP medium contained (per litre distilled water): $1.0 \mathrm{~g} \mathrm{MgSO}_{4} \cdot 7 \mathrm{H}_{2} \mathrm{O}, 10.0 \mathrm{~g}$ yeast extract (Difco), $5.0 \mathrm{~g}$ peptone (Difco) and $1.0 \mathrm{~g}$ glucose ( $\mathrm{pH}$ 7.5). The $\mathrm{pH}$ range for growth (from $\mathrm{pH} 5.0$ to 10.0, at intervals of $0.5 \mathrm{pH}$ units) was determined in $\mathrm{HM}$ with the addition of MES (50 mM; pH 5.0-6.5), PIPES (50 mM; pH 6.5-7.5), Tris (50 mM; pH 7.5-9.0) or $\mathrm{Na}_{2} \mathrm{CO}_{3} / \mathrm{NaHCO}_{3}$ (pH 9.0-10.0). The temperature range for growth was determined by incubating at $4,10,15,20$, $25,30,35,37,40,42,45$ and $50{ }^{\circ} \mathrm{C}$. Cell morphology and motility were examined by using optical microscopy (BX40; Olympus) and electron microscopy (JEM-1200EX; JEOL).

Single carbon-source assimilation tests were performed by using a basal medium (Kämpfer et al., 1991) containing (per litre distilled water): $30.0 \mathrm{~g} \mathrm{NaCl}, 0.5 \mathrm{~g} \mathrm{MgSO}_{4} .7 \mathrm{H}_{2} \mathrm{O}, 0.1 \mathrm{~g}$ $\mathrm{CaCl}_{2} .2 \mathrm{H}_{2} \mathrm{O}, \quad 1.74 \mathrm{~g} \quad \mathrm{~K}_{2} \mathrm{HPO}_{4}, \quad 1.36 \mathrm{~g} \quad \mathrm{KH}_{2} \mathrm{PO}_{4}, \quad 5 \mathrm{~g}$ $\left(\mathrm{NH}_{4}\right)_{2} \mathrm{SO}_{4}, 0.02 \mathrm{~g}$ yeast extract (Difco), $0.02 \mathrm{~g}$ peptone (Difco), $1 \mathrm{ml}$ vitamin mixture solution (Wolin et al., 1963), $5 \mathrm{ml}$ mineral mixture solution (Balch et al., 1979) and $25 \mathrm{mM}$ PIPES ( $\mathrm{pH}$ 7.2). The corresponding filter-sterilized sugar $(0.2 \%)$, alcohol $(0.1 \%)$, organic acid $(0.1 \%)$ or amino acid $(0.1 \%)$ was added to the liquid medium. Acid production was tested by using modified MOF medium supplemented with $1 \%$ sugars (Leifson, 1963; Xu et al., 2008). Biochemical and nutritional tests were performed in $\mathrm{HM}$ according to Xu et al. (2007) as described by Mata et al. (2002). Additional enzyme activities and biochemical characteristics were determined by using API 20E, API 20NE and API ZYM kits at $37{ }^{\circ} \mathrm{C}$ as recommended by the manufacturer (bioMérieux). P. sediminum CICC $10319^{\mathrm{T}}$ was used as a control in these tests.

Genomic DNA was obtained by using the method described by Marmur (1961). The 16S rRNA gene was amplified and analysed as described by Xu et al. (2007). PCR products were cloned into pMD19-T vector (TaKaRa) and were then sequenced to determine the almostcomplete sequence of the 16S rRNA gene. The sequence was compared with those of closely related reference organisms from the FASTA and EzTaxon services (Chun et al., 2007). Sequence data were aligned with CLUSTAL W 1.8 (Thompson et al., 1994). Phylogenetic trees were constructed according to the neighbour-joining (Saitou \& Nei, 1987) and maximum-parsimony (Fitch, 1971) methods with the MEGA 3.1 program package (Kumar et al., 2004), and according to the maximum-likelihood method (Felsenstein, 1981) with the TreePuzzle 5.2 program. Evolutionary distances were calculated based on the algorithm of the Kimura two-parameter model (Kimura, 1980) for the neighbour-joining method.

Cellular fatty acid methyl esters were prepared from cells grown on MA for 2 days at $30{ }^{\circ} \mathrm{C}$ and were analysed by using GC/MS (Kuykendall et al., 1988), according to the instructions of the Microbial Identification System (MIDI
Inc.). Isoprenoid quinones were extracted from freezedried cells $(200 \mathrm{mg})$ with chloroform/methanol $(2: 1$, by vol.) and were analysed by using reversed-phase HPLC. The purified DNA was hydrolysed with P1 nuclease and the nucleotides were dephosphorylated with calf intestine alkaline phosphatase (Mesbah \& Whitman, 1989). The $\mathrm{G}+\mathrm{C}$ contents of the resulting deoxyribonucleosides were determined by reversed-phase HPLC and were calculated from the ratio of deoxyguanosine $(\mathrm{dG})$ and thymidine $(\mathrm{dT})$ (Mesbah \& Whitman, 1989). DNA-DNA hybridizations were performed by using the thermal denaturation and renaturation method of De Ley et al. (1970) as modified by Huß et al. (1983), with a Beckman DU 800 spectrophotometer.

Cells of strains $908033^{\mathrm{T}}$ and $908087^{\mathrm{T}}$ were Gram-negative, slightly curved rods that were motile by means of peritrichous flagella (see Supplementary Fig. S1, in IJSEM Online). The $\mathrm{NaCl}$ concentration and temperature ranges for growth of strain $908033^{\mathrm{T}}$ were $0.5-10.0 \%(\mathrm{w} / \mathrm{v})$ and $15-45{ }^{\circ} \mathrm{C}$, whereas those of strain $908087^{\mathrm{T}}$ were $0.5-15.0 \%$ $(\mathrm{w} / \mathrm{v})$ and $10-45{ }^{\circ} \mathrm{C}$. Strain $908033^{\mathrm{T}}$ could be distinguished from strain $908087^{\mathrm{T}}$ based on $\mathrm{H}_{2} \mathrm{~S}$ formation, selenite reduction, lecithinase production and tyrosine hydrolysis (Table 1). Physiological and chemotaxonomic characteristics of the two strains are summarized in the species descriptions below.

Almost-complete 16S rRNA gene sequences of strains $908033^{\mathrm{T}}$ (1507 nt) and $908087^{\mathrm{T}}$ (1507 nt) were obtained. The two strains were found to be phylogenetically closely related, showing $97.5 \% 16 \mathrm{~S}$ rRNA gene sequence similarity (Fig. 1). 16S rRNA gene sequence comparisons with representative bacteria with validly published names indicated that strains $908033^{\mathrm{T}}$ and $908087^{\mathrm{T}}$ were related most closely to members of the genera Pseudidiomarina (95.8-96.6\% similarity) and Idiomarina (93.7-97.5\%). Phylogenetic analysis based on 16S rRNA gene sequences showed that the novel isolates formed a coherent cluster with the type strains of $P$. taiwanensis and $P$. sediminum with a moderately high bootstrap resampling value $(71 \%$ based on the neighbour-joining method) (Fig. 1). The topologies of the phylogenetic trees constructed by using the maximum-likelihood and maximum-parsimony algorithms also supported the suggestion that strains $908033^{\mathrm{T}}$ and $908087^{\mathrm{T}}$ represent novel species of the genus Pseudidiomarina (Supplementary Fig. S2, in IJSEM Online). The major cellular fatty acids of strains $908033^{\mathrm{T}}$ and $908087^{\mathrm{T}}$ were iso- $\mathrm{C}_{15: 0}(22.9$ and $26.8 \%$ of the total, respectively), iso- $\mathrm{C}_{17: 0}(23.1$ and $15.4 \%)$ and iso- $\mathrm{C}_{17: 1} \omega 9 \mathrm{c}$ (12.5 and $11.6 \%$ ) (Supplementary Table S1, available in IJSEM Online). This profile was similar to that of recognized species of the genus Pseudidiomarina (Jean et al., 2006; Hu \& Li., 2007).

Strains $908033^{\mathrm{T}}$ and $908087^{\mathrm{T}}$ showed less than $97.0 \% 16 \mathrm{~S}$ rRNA gene sequence similarity to the type strains of the two recognized species of the genus Pseudidiomarina. Levels of DNA-DNA relatedness between strains $908033^{\mathrm{T}}$ 
Table 1. Differential taxonomic characteristics between strains $908033^{\top}\left(P\right.$. donghaiensis sp. nov.) and $908087^{\top}(P$. maritima sp. nov.) and other related Pseudidiomarina and Idiomarina species

Strains: $1,908033^{\mathrm{T}}$ (data from the present study); $2,908087^{\mathrm{T}}$ (present study); 3, P. sediminum CICC $10319^{\mathrm{T}}$ (present study); 4, $P$. taiwanensis $\mathrm{PIT}^{\mathrm{T}}$ (Jean et al., 2006); 5, I. salinarum ISL-52 ${ }^{\mathrm{T}}$ (Yoon et al., 2007). +, Positive; -, negative; ND, not determined. Phenotypic tests for P. sediminum CICC $10319^{\mathrm{T}}$ were performed in parallel with those for strains $908033^{\mathrm{T}}$ and $908087^{\mathrm{T}}$.

\begin{tabular}{|lccccc|}
\hline Characteristic & $\mathbf{1}$ & $\mathbf{2}$ & $\mathbf{3}$ & $\mathbf{4}$ & $\mathbf{5}$ \\
\hline Motility & + & + & - & - & + \\
Growth in $12 \% \mathrm{NaCl}$ & - & + & + & - & + \\
Growth at $10{ }^{\circ} \mathrm{C}$ & - & + & - & - & + \\
Growth at $45{ }^{\circ} \mathrm{C}$ & + & + & - & - & - \\
Catalase & + & + & $-*$ & + & + \\
Nitrate reduction & - & - & - & + & + \\
Production of $\mathrm{H}_{2} \mathrm{~S}$ & + & - & - & - & $\mathrm{ND}$ \\
Selenite reduction & - & + & + & $\mathrm{ND}$ & $\mathrm{ND}$ \\
Lecithinase & + & - & + & $\mathrm{ND}$ & $\mathrm{ND}$ \\
Hydrolysis of: & & & & & \\
$\quad$ Casein & + & + & + & - & - \\
$\quad$ DNA & + & + & $-*$ & - & + \\
$\quad$ Tyrosine & + & - & + & $\mathrm{ND}$ & + \\
Susceptibility to: & & & & & \\
$\quad$ Penicillin & + & + & - & + & - \\
$\quad$ Polymyxin B & + & + & - & + & + \\
DNA G $+\mathrm{C}$ content (mol\%) & 45.5 & 45.2 & $50.0^{*}$ & 49.3 & 53.9 \\
$\quad$ by HPLC) & & & & & \\
\hline
\end{tabular}

${ }^{\star}$ Data from Hu \& Li (2007).

and $908087^{\mathrm{T}}$ with respect to $P$. sediminum CICC $10319^{\mathrm{T}}$ were 39.1 and $37.5 \%$, respectively. A low level of DNADNA relatedness $(41.3 \%)$ was found between strains
$908033^{\mathrm{T}}$ and $908087^{\mathrm{T}}$, suggesting that the two strains represent two species of the genus Pseudidiomarina (Stackebrandt \& Goebel, 1994). Comparison of phenotypic properties (Table 1 and Supplementary Table S1) indicated differences between strains $908033^{\mathrm{T}}$ and $908087^{\mathrm{T}}$ and the type strains of $P$. taiwanensis and $P$. sediminum, such as motility, salt or temperature range for growth, nitrate reduction, $\mathrm{H}_{2} \mathrm{~S}$ formation, hydrolysis of substrates, susceptibility to antimicrobial compounds and DNA G $+\mathrm{C}$ content.

Based on 16S rRNA gene sequence analysis, as well as the DNA-DNA hybridization data and differential phenotypic properties, we suggest that strains $908033^{\mathrm{T}}$ and $908087^{\mathrm{T}}$ represent two novel species of the genus Pseudidiomarina, for which the names Pseudidiomarina donghaiensis sp. nov. and Pseudidiomarina maritima sp. nov. are proposed, respectively.

\section{Description of Pseudidiomarina donghaiensis sp. nov.}

Pseudidiomarina donghaiensis (dong.ha.i.en'sis. N.L. fem. adj. donghaiensis pertaining to Donghai, the Chinese name for the East China Sea).

Cells are Gram-negative, slightly curved rods, approximately $0.4-0.6 \mu \mathrm{m}$ in width and $1.0-1.4 \mu \mathrm{m}$ in length. Cells are motile by means of peritrichous flagella. No endospores are formed. Colonies on MA plates are 1-2 mm in diameter, non-pigmented, circular and smooth after $48 \mathrm{~h}$ at $37{ }^{\circ} \mathrm{C}$. Growth occurs at $\mathrm{NaCl}$ concentrations of $0.5-$ $10.0 \%(\mathrm{w} / \mathrm{v})$ with optimum growth at $3.0 \%$. pH and temperature ranges for growth are $\mathrm{pH} 6.5-10.0$ and 15$45{ }^{\circ} \mathrm{C}$ (optimum growth at $\mathrm{pH} 8.0-9.0$ and $37^{\circ} \mathrm{C}$ ). No growth is detected at 10 or $50{ }^{\circ} \mathrm{C}$. Positive for oxidase and catalase. No growth occurs on MacConkey agar or cetrimide agar. Casein, gelatin, DNA, Tweens 20 and 80 and tyrosine are hydrolysed. Aesculin and starch are not

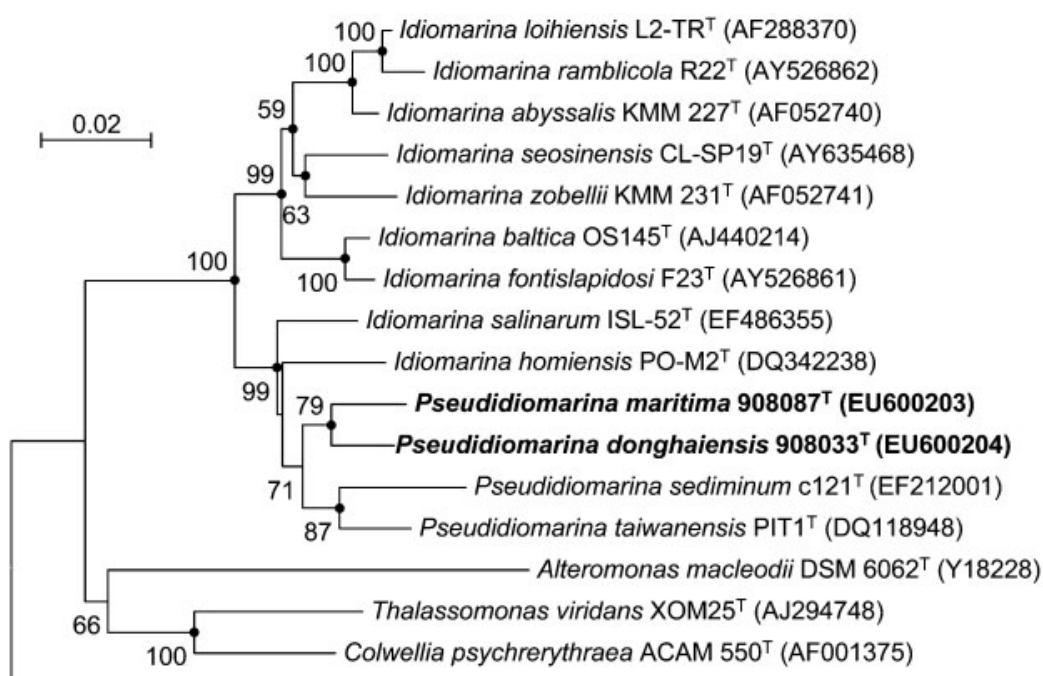

Pseudomonas aeruginosa DSM $50071^{\top}(\mathrm{X} 06684)$
Fig. 1. Neighbour-joining tree based on $16 \mathrm{~S}$ rRNA gene sequences, showing the phylogenetic relationships among strains $908033^{\top}$ and $908087^{\top}$ and related taxa. Bootstrap values are based on 1000 replicates; only values $>50 \%$ are shown. Bar, 0.02 substitutions per nucleotide position. Filled circles indicate nodes that were also recovered with bootstrap values $>50 \%$ in both the maximumlikelihood and the maximum-parsimony trees (see Supplementary Fig. S2a, b). 
hydrolysed. Positive for lecithinase. Negative for arginine dihydrolase, gluconate oxidation, indole production, lysine decarboxylase, methyl red, $o$-nitrophenyl $\beta$-D-galactopyranosidase, ornithine decarboxylase, selenite reduction and urease. Produces $\mathrm{H}_{2} \mathrm{~S}$ from thiosulfate. No nitrate or nitrite reduction. The following substrates are not utilized as sole carbon and energy sources: acetate, adonitol, L-alanine, Larabinose, L-arginine, L-asparagine, L-aspartate, D-cellobiose, citrate, L-cysteine, ethanol, formate, D-fructose, fumarate, D-galactose, glucose, L-glutamate, glycerol, glycine, gluconate, L-glutamine, L-histidine, inositol, isoleucine, lactate, lactose, lysine, malate, malonate, maltose, mannitol, D-mannose, melibiose, L-methionine, L-proline, propionate, pyruvate, D-raffinose, rhamnose, ribose, salicin, L-serine, L-sorbitol, sorbose, succinate, sucrose, trehalose, L-valine, xylitol and xylose. Acid is not produced from adonitol, L-arabinose, D-cellobiose, D-fructose, Dgalactose, glucose, inositol, lactose, maltose, mannitol, Dmannose, melibiose, D-raffinose, rhamnose, ribose, Lsorbitol, sorbose, sucrose, trehalose, xylitol or xylose. The following constitutive enzyme activities are detected in API ZYM tests: alkaline phosphatase, esterase (C4), esterase lipase (C8), lipase (C14), leucine arylamidase, valine arylamidase, cystine arylamidase, trypsin, $\alpha$-chymotrypsin, acid phosphatase and naphthol-AS-BI-phosphohydrolase. In API 20NE tests, negative for use of any of the substrates provided with the kit except gelatin. In API 20E tests, produces gelatinase, but cannot ferment glucose or other carbohydrates as substrates. Susceptible to amoxicillin $(10 \mu \mathrm{g})$, ampicillin $(10 \mu \mathrm{g})$, carbenicillin $(100 \mu \mathrm{g})$, cefotaxime $(30 \mu \mathrm{g})$, cefoxitin $(30 \mu \mathrm{g})$, chloramphenicol $(30 \mu \mathrm{g})$, erythromycin $(10 \mu \mathrm{g})$, minocycline $(30 \mu \mathrm{g})$, nitrofurantoin $(300 \mu \mathrm{g})$, novobiocin $(30 \mu \mathrm{g})$, penicillin (10 IU), polymyxin B (300 IU), rifampicin $(5 \mu \mathrm{g})$ and tetracycline $(30 \mu \mathrm{g})$, but resistant to bacitracin (0.04 IU), kanamycin $(30 \mu \mathrm{g})$, neomycin $(30 \mu \mathrm{g})$, nystatin $(100 \mu \mathrm{g})$ and tobramycin $(10 \mu \mathrm{g})$. The predominant ubiquinone is Q-8. Major fatty acids are iso- $\mathrm{C}_{15: 0}$, iso- $\mathrm{C}_{17: 0}$ and iso- $\mathrm{C}_{17: 1} \omega 9 c$. The DNA G $+\mathrm{C}$ content of the type strain is $45.5 \mathrm{~mol} \%$ (determined by HPLC).

The type strain, $908033^{\mathrm{T}} \quad\left(=\mathrm{CGMCC} \quad 1.7284^{\mathrm{T}}=\mathrm{JCM}\right.$ $15533^{\mathrm{T}}$ ), was isolated from a coastal seawater sample collected from the East China Sea, China.

\section{Description of Pseudidiomarina maritima sp. nov.}

Pseudidiomarina maritima (ma.ri.ti'ma. L. fem. adj. maritima inhabiting marine environments).

Cells are Gram-negative, slightly curved rods, approximately $0.4-0.6 \mu \mathrm{m}$ wide and $1.4-2.0 \mu \mathrm{m}$ long. Cells are motile by means of peritrichous flagella. Colonies on MA plates are 1-2 $\mathrm{mm}$ in diameter, non-pigmented, circular and smooth after $48 \mathrm{~h}$ at $37{ }^{\circ} \mathrm{C}$. Growth occurs at $\mathrm{NaCl}$ concentrations of $0.5-15.0 \%(\mathrm{w} / \mathrm{v})$ with optimum growth at $3.0 \%$. The $\mathrm{pH}$ and temperature ranges for growth are $\mathrm{pH} 6.5-10.0$ and $10-45{ }^{\circ} \mathrm{C}$ (optimum growth at $\mathrm{pH} 8.0-$ 9.0 and $37{ }^{\circ} \mathrm{C}$ ). No growth is detected at 4 or $50{ }^{\circ} \mathrm{C}$.
Positive for oxidase and catalase. No growth occurs on MacConkey agar or cetrimide agar. Casein, DNA, gelatin and Tweens 20 and 80 are hydrolysed. Aesculin, starch and tyrosine are not hydrolysed. Positive for selenite reduction. Negative for arginine dihydrolase, gluconate oxidation, indole production, lecithinase, lysine decarboxylase, methyl red, $o$-nitrophenyl $\beta$-D-galactopyranosidase, ornithine decarboxylase and urease. $\mathrm{H}_{2} \mathrm{~S}$ is not formed from thiosulfate. No nitrate or nitrite reduction. The following substrates are not utilized as sole carbon and energy sources: acetate, adonitol, L-alanine, L-arabinose, Larginine, L-asparagine, L-aspartate, D-cellobiose, citrate, Lcysteine, ethanol, formate, D-fructose, fumarate, D-galactose, glucose, L-glutamate, glycerol, glycine, gluconate, Lglutamine, L-histidine, inositol, isoleucine, lactate, lactose, lysine, malate, malonate, maltose, mannitol, D-mannose, melibiose, L-methionine, L-proline, propionate, pyruvate, D-raffinose, rhamnose, ribose, salicin, L-serine, L-sorbitol, sorbose, succinate, sucrose, trehalose, L-valine, xylitol and xylose. Acid is not produced from: adonitol, L-arabinose, D-cellobiose, D-fructose, D-galactose, glucose, inositol, lactose, maltose, mannitol, D-mannose, melibiose, Draffinose, rhamnose, ribose, L-sorbitol, sorbose, sucrose, trehalose, xylitol or xylose. The following constitutive enzyme activities are detected in API ZYM tests: alkaline phosphatase, esterase (C4), esterase lipase (C8), lipase (C14), leucine arylamidase, valine arylamidase, cystine arylamidase, trypsin, $\alpha$-chymotrypsin, acid phosphatase and naphthol-AS-BI-phosphohydrolase. In API 20NE tests, the type strain is not able to use any of the substrates provided with the kit except gelatin. In API 20E tests, the type strain produces gelatinase, but cannot ferment glucose or other carbohydrates as substrates. Susceptible to amoxicillin $(10 \mu \mathrm{g})$, ampicillin $(10 \mu \mathrm{g})$, carbenicillin $(100 \mu \mathrm{g})$, cefotaxime $(30 \mu \mathrm{g})$, cefoxitin $(30 \mu \mathrm{g})$, chloramphenicol $(30 \mu \mathrm{g})$, erythromycin $(10 \mu \mathrm{g})$, minocycline $(30 \mu \mathrm{g})$, nitrofurantoin $(300 \mu \mathrm{g})$, novobiocin $(30 \mu \mathrm{g})$, penicillin $(10 \mathrm{IU})$, polymyxin $\mathrm{B}$ (300 IU), rifampicin $(5 \mu \mathrm{g})$ and tetracycline $(30 \mu \mathrm{g})$, but resistant to bacitracin $(0.04 \mathrm{IU})$, kanamycin $(30 \mu \mathrm{g})$, neomycin $(30 \mu \mathrm{g})$, nystatin $(100 \mu \mathrm{g})$ and tobramycin $(10 \mu \mathrm{g})$. The predominant ubiquinone is Q-8. Major fatty acids are iso$\mathrm{C}_{15: 0}$, iso- $\mathrm{C}_{17: 0}$ and iso- $\mathrm{C}_{17: 1} \omega 9 c$. The DNA $\mathrm{G}+\mathrm{C}$ content of the type strain is $45.2 \mathrm{~mol} \%$ (determined by HPLC).

The type strain, $908087^{\mathrm{T}} \quad\left(=\mathrm{CGMCC} \quad 1.7285^{\mathrm{T}}=\mathrm{JCM}\right.$ $15534^{\mathrm{T}}$ ), was isolated from a coastal seawater sample collected from the East China Sea, China.

\section{Acknowledgements}

We thank Jean Euzéby for his help with the specific etymology and nomenclature. This work was supported by grants from the Major State Basic Research Development Program of China (973 Program) (2004CB719604-3), the Scientific Research Fund of the Second Institute of Oceanography, SOA (JT0709), the Chinese Offshore Investigation and Assessment (908-ZC-I-02), the National High Technology Research and Development Program of China (863 
Program) (2007AA021305) and the National Infrastructure of Natural Resources for Science and Technology (2005DKA21206).

\section{References}

Balch, W. E., Fox, G. E., Magrum, L. J., Woese, C. R. \& Wolfe, R. S. (1979). Methanogens: reevaluation of a unique biological group. Microbiol Rev 43, 260-296.

Chun, J., Lee, J. H., Jung, Y., Kim, M., Kim, S., Kim, B. K. \& Lim, Y. W. (2007). EzTaxon: a web-based tool for the identification of prokaryotes based on $16 \mathrm{~S}$ ribosomal RNA gene sequences. Int J Syst Evol Microbiol 57, 2259-2261.

De Ley, J., Cattoir, H. \& Reynaerts, A. (1970). The quantitative measurement of DNA hybridization from renaturation rates. Eur $J$ Biochem 12, 133-142.

Felsenstein, J. (1981). Evolutionary trees from DNA sequences: a maximum likelihood approach. J Mol Evol 17, 368-376.

Fitch, W. M. (1971). Toward defining the course of evolution: minimum change for a specific tree topology. Syst Zool 20, 406-416.

Hu, Z. Y. \& Li, Y. (2007). Pseudidiomarina sediminum sp. nov., a marine bacterium isolated from coastal sediments of Luoyuan Bay in China. Int J Syst Evol Microbiol 57, 2572-2577.

Huß, V. A. R., Festl, H. \& Schleifer, K. H. (1983). Studies on the spectrophotometric determination of DNA hybridization from renaturation rates. Syst Appl Microbiol 4, 184-192.

Ivanova, E. P., Romanenko, L. A., Chun, J., Matte, M. H., Matte, G. R., Mikhailov, V. V., Svetashev, V. I., Huq, A., Maugel, T. \& Colwell, R. R. (2000). Idiomarina gen. nov., comprising novel indigenous deep-sea bacteria from the Pacific Ocean, including descriptions of two species, Idiomarina abyssalis sp. nov. and Idiomarina zobellii sp. nov. Int J Syst Evol Microbiol 50, 901-907.

Ivanova, E. P., Flavier, S. \& Christen, R. (2004). Phylogenetic relationships among marine Alteromonas-like proteobacteria: emended description of the family Alteromonadaceae and proposal of Pseudoalteromonadaceae fam. nov., Colwelliaceae fam. nov., Shewanellaceae fam. nov., Moritellaceae fam. nov., Ferrimonadaceae fam. nov., Idiomarinaceae fam. nov. and Psychromonadaceae fam. nov. Int J Syst Evol Microbiol 54, 1773-1788.

Jean, W. D., Shieh, W. Y. \& Chiu, H.-H. (2006). Pseudidiomarina taiwanensis gen. nov., sp. nov., a marine bacterium isolated from shallow coastal water of An-Ping Harbour, Taiwan, and emended description of the family Idiomarinaceae. Int J Syst Evol Microbiol 56, 899-905.

Kämpfer, P., Steiof, M. \& Dott, W. (1991). Microbiological characterization of a fuel-oil contaminated site including numerical identification of heterotrophic water and soil bacteria. Microb Ecol 21, 227-251.
Kimura, M. (1980). A simple method for estimating evolutionary rates of base substitutions through comparative studies of nucleotide sequences. J Mol Evol 16, 111-120.

Kumar, S., Tamura, K. \& Nei, M. (2004). MEGA3: integrated software for molecular evolutionary genetics analysis and sequence alignment. Brief Bioinform 5, 150-163.

Kuykendall, L. D., Roy, M. A., O'Neill, J. J. \& Devine, T. E. (1988). Fatty acids, antibiotic resistance, and deoxyribonucleic acid homology groups of Bradyrhizobium japonicum. Int J Syst Bacteriol 38, 358-361.

Leifson, E. (1963). Determination of carbohydrate metabolism of marine bacteria. J Bacteriol 85, 1183-1184.

Marmur, J. (1961). A procedure for the isolation of deoxyribonucleic acid from microorganisms. J Mol Biol 3, 208-218.

Mata, J. A., Martínez-Cánovas, J., Quesada, E. \& Béjar, V. (2002). A detailed phenotypic characterisation of the type strains of Halomonas species. Syst Appl Microbiol 25, 360-375.

Mesbah, M. \& Whitman, W. B. (1989). Measurement of deoxyguanosine/thymidine ratios in complex mixtures by high-performance liquid chromatography for determination of the mole percentage guanine + cytosine of DNA. J Chromatogr 479, 297-306.

Saitou, N. \& Nei, M. (1987). The neighbor-joining method: a new method for reconstructing phylogenetic trees. Mol Biol Evol 4, 406-425.

Stackebrandt, E. \& Goebel, B. M. (1994). Taxonomic note: a place for DNA-DNA reassociation and $16 \mathrm{~S}$ rRNA sequence analysis in the present species definition in bacteriology. Int J Syst Bacteriol 44, 846849.

Thompson, J. D., Higgins, D. G. \& Gibson, T. J. (1994). CLUSTAL W: improving the sensitivity of progressive multiple sequence alignment through sequence weighting, position-specific gap penalties and weight matrix choice. Nucleic Acids Res 22, 4673-4680.

Ventosa, A., Quesada, E., Rodriguez-Valera, F., Ruiz-Berraquero, F. \& Ramos-Cormenzana, A. (1982). Numerical taxonomy of moderately halophilic Gram-negative rods. J Gen Microbiol 128, 1959-1968.

Wolin, E. A., Wolin, M. J. \& Wolfe, R. S. (1963). Formation of methane by bacterial extracts. J Biol Chem 238, 2882-2886.

Xu, X.-W., Wu, Y.-H., Zhou, Z., Wang, C.-S., Zhou, Y.-G., Zhang, H.-B., Wang, Y. \& Wu, M. (2007). Halomonas saccharevitans sp. nov., Halomonas arcis sp. nov. and Halomonas subterranea sp. nov., halophilic bacteria isolated from hypersaline environments of China. Int J Syst Evol Microbiol 57, 1619-1624.

Xu, X.-W., Wu, Y.-H., Wang, C.-S., Yang, J.-Y., Oren, A. \& Wu, M. (2008). Marinobacter pelagius sp. nov., a moderately halophilic bacterium. Int J Syst Evol Microbiol 58, 637-640.

Yoon, J.-H., Jung, S.-Y., Jung, Y.-T. \& Oh, T.-K. (2007). Idiomarina salinarum sp. nov., isolated from a marine solar saltern in Korea. Int $J$ Syst Evol Microbiol 57, 2503-2506. 